Vol. 18, n² | 2014

Varia

\title{
Confronting terrorism: British Experiences past and present
}

\section{Georgina Sinclair}

\section{(2) OpenEdition \\ 1 Journals}

\section{Electronic version}

URL: http://journals.openedition.org/chs/1495

DOI: $10.4000 /$ chs. 1495

ISSN: 1663-4837

\section{Publisher}

Librairie Droz

\section{Printed version}

Date of publication: 1 October 2014

Number of pages: 117-122

ISBN: 978-2-600-01854-8

ISSN: $1422-0857$

\section{Electronic reference}

Georgina Sinclair, "Confronting terrorism: British Experiences past and present », Crime, Histoire \& Sociétés / Crime, History \& Societies [Online], Vol. 18, n² | 2014, Online since 01 October 2017, connection on 22 September 2020. URL : http://journals.openedition.org/chs/1495 ; DOI : https:// doi.org/10.4000/chs. 1495 


\section{Lecture croisée Review Essay \\ Confronting terrorism: British Experiences past and present}

David Brown, The European Union, counter terrorism and police co-operation, 1992-2007, Manchester, Manchester University Press, 2010, 204 pp., ISBN 9 78071907464.

David French, The British Way in Counter-Insurgency 1945-1967, Oxford, OUP, 2011, 283 pp., ISBN 9780199587964.

Robert Lambert, Countering Al-Qaeda in London: Police and Muslims in Partnership, London, Hurst \& co., 2011, 402 pp., ISBN 978184904.

Confronting terrorism has been a principal objective of the United States and other Western governments since the mid-1990s. The watershed of the 9/11 attacks in 2001 harnessed calls for more comprehensive and sophisticated counter-terrorism strategies to be instigated on a global basis. By extension the United Kingdom has a history of confronting terrorist challenges both domestically and overseas, within a colonial and post-colonial context and later in collaboration with its European and US partners. This general theme underpins each of these three excellent books which in turn detail a range of counter-insurgency and counter-terrorist policies and practices developed from 1945 to the present day. Together and from differing perspectives, the three address issues of contemporary history and link these closely to contemporary state practice.

In The British Way in Counter-Insurgency, the historian David French presents a revisionist analysis of counter-insurgency and counter-terrorism conducted through the military, policing and administrative lens of ten colonial campaigns from 1945 through to the withdrawal from Aden in 1967. Using an impressive array of primary and secondary sources, French explores the "brutality of empire", the state's use of coercive mechanisms as integral to the successful implementation of British policy. Here French aims to redirect our understanding of the management of this era of decolonisation - and particularly the traditional view of COIN that remains entrenched within policy-makers and the military - so that present day conflict and hostile environment situations might be approached with greater insight. Considering counter-terrorism in the contemporary period, David Brown's European Union, counter terrorism and police co-operation scrutinises the difficulties states have faced with the integration of counter-terrorist policies into European Union government structures. As such this book delivers a substantive analysis of pre - and post-9/11 Europe in relation to unfolding counter-terrorism strategies and the building of European-wide police co-operation, considering the "true impact of this event". Europe's approach to counter-terrorism as Brown notes has had wider ramifications following the bombings in Madrid in 2004 and in London 7/7 2005 - as well as a 
host of other incidents. This has led to further changes within the legislation and attempts at police-building across all member states with significant implications for the citizen. The difficulties faced by police officers in delivering effective counterterrorism at grass roots level are exposed in Robert Lambert's Countering Al-Qaeda in London. Lambert is a former Metropolitan police Special Branch officer who has detailed the journey taken between 2002 and 2007 to pioneer "controversial counterterrorism partnership projects" with Muslim communities in London. Lambert has used this memoir to "challenge" British counter-terrorist policy and strategy which he argues has "undermined" the international reputation of British policing. The policing that earned this reputation, he feels, is needed to encourage the government to work with radical but non-violent Muslim organisations.

In essence each of these three books chart the state's - and most specifically the United Kingdom's - changing (and often hidden) approaches to counter-terrorism from a post-colonial Cold War world to the so-called 'War on Terror' today. They provide an opportunity to consider whether a 'British' way has had impact not only domestically but within a wider European and international context. They contribute to the newer writings of British counter-insurgency and counter-terrorism which expose the darker sides to that 'British' way. As Lambert notes: one of the "many negative unintended consequences of the War on Terror has been the juxtaposition of international policing methods in which the Peelian notion of 'policing by consent' has often been overshadowed and eclipsed by the practice of state terror, torture and coercion". Indeed each of these books serves as a reminder of the uneasy line drawn between the state and the citizen in maintaining a democratic status quo when confronted by acts of terrorism or serious public unrest.

A widely held view is that terrorism is essentially a pre-meditated political act which is not simply aimed at specific victims but typically impacts upon a far wider audience. The tactics used by the different agencies - government departments, the military, law enforcement agencies, intelligence agencies, emergency services and any other groups situated within society are essentially in response to a need to impose order and regain sovereignty. In the Western world the range of counterterrorist measures have been embedded within a wider criminal justice framework. However, the post-1945 era saw the UK, Europe and the wider world increasingly challenged by insurgency and terrorist activities which necessitated a common approach. Twenty-first-century counter-terrorist strategies adopted by the UK have become subsumed within a US global War on Terror. In essence the UK has had to learn how to operate within a multi-agency and multinational environment and to build the necessary relationships. As Al-Qaeda has become identified as the 'new' terrorist threat there has been a move away from the historic 'old' terrorism in the UK which came principally from Northern-Ireland-related organisations.

The earlier counter-terrorist strategies that emerged in Northern Ireland stemmed from a colonial root and the earlier British experiences of its small colonial wars. As French points out in The British Way in Counter-Insurgency, a golden age of British counter-insurgency experiences occurred post-1945 including Malaya (1948-1960); Kenya (1952-1956); Cyprus (1955-1960) and Oman (1965-1975). Each has been held to be a 'classical' counter-insurgency campaign contributing to the management of the Northern Ireland conflict. In particular, as French argues, 
the Malayan 'doctrine' as pioneered by Sir Henry Gurney, Sir Harold Briggs, General Sir Gerald Templer and Sir Robert Thompson became a British showcase for classical counter-insurgency warfare that the military in other countries could emulate. As French's thesis progresses, he demolishes the traditional 'hearts and minds' myth that lay at the core of the British way. His analysis of the 'British' approach to counter-insurgency as practiced by soldiers, colonial police, security services, administrators and Whitehall politicians demonstrates that many were not "always committed to fighting with kid gloves" when it came to managing the end of empire. This remains an important issue, argues French, and not simply in relation to historical enquiry but in relation to the misunderstandings that have surrounded British counter-insurgency which has continued to inform British military doctrine and practice even to this day. Nonetheless, the British solution to colonial conflict and profound social unrest rested upon the practice of the 'Malayan Model' through the concept of the 'three-legged stool': the co-ordination of efforts by the military, colonial police and administration. Whether it could be judged successful, as far as the British were concerned, hinged upon the extent to which this concept was replicated in other parts of the empire and beyond. On the ground, the practical failures that ensued (for example a paucity in intelligence gathering and analysis) necessitated a 'sledge hammer' approach towards the local population which included mass-arrests, detentions, cordons and searches and collective punishments. Part of this British way lay in the perception of who constituted an enemy of the state - the 'Malayan Model' of counter-insurgency laid emphasis on defeating the military opponents as well as political subversives. In doing so this British way may have failed to fully balance the needs of different communities alongside the ability to detect exactly who was that enemy of the state. In Palestine, for example, French notes how the British faced difficulties in addressing the very different needs of the Jewish and Arab communities. This was also true of Cyprus where $80 \%$ of the island's ethnic Greek population (who sought union with Greece) were opposed by the remaining $20 \%$ of the ethnic Turkish population. In both cases the British were hard put to balance the political and military aspirations of the individual parties and often misdirected reappraisals, clamping down on the local population. So "far from accepting their enemies had genuine grievances" the British had a tendency to resort to marginalisation and criminalisation. The paradox to all of this was a genuine belief upheld that the British way was not only the 'right approach' but grounded in paternalism.

Using coercive approaches, however veiled, was also important, notes French, to maintaining discipline amongst those soldiers and police officers who were often called to make a judgement that their actions were aligned with the rule of law. Here the British approach was to maintain the outward appearance of legality: the 1939 Emergency Powers Order in Council informed both the military and police operationally, allowed for the suspension of ordinary law and initially became the legal basis of emergency situations in Kenya, Cyprus and Nyasaland. These emergency powers were then combined with local legislation to frame emergency regulations within a specific colonial environment. In essence emergency regulations were about British forces 'taking the war to the enemy', 'harassing insurgents' and, if necessary, intimidating the local population. This could include the use of collective punishment (fines, curfews and so on), mass-arrests, and detention without trial, deportation and resettlement. In effect these became 'control regulations' which 
allowed the colonial state to widen the definition of criminalisation and punishment (including the death penalty). This, French notes, may have been legal but was certainly not legitimate and coercive approaches - which amounted effectively to 'police state controls' - paved the way for Britain's 'dirty wars' which included unofficial reprisals against the population, the use of 'death squads', interrogation and torture and detention without trial. However, the problem with the use of an excessively coercive approach is that 'hearts and minds' will not be won. Coercion, therefore, was not the only 'weapon in the British counter-insurgents armoury'; both the insurgents and the civil population were courted through political, economic, social and cultural development. This too, argues French, had a flip side. The use of psychological warfare (or Psychops) to help 'turn' insurgents was undertaken through intimidation as well as offering financial incentives. Colonial development programmes underpinned by the Colonial Development and Welfare Acts, were largely funded by the colonies: between 1946 and 1957 approximately $£ 1,000$ million was spent on projects intended to develop colonial economies, improve health and education and so on of which $60 \%$ emanated from their own tax revenues and a further $18.7 \%$ from international loans which became a burden on individual colonies. It was only in the case of far smaller civic action 'grass roots' programmes that real aid was provided to local populations but once again at a price. In the wake of the Radfan Campaign, for example in 1964, British troops distributed supplies of flour, oil, grain and tea to the local tribes once peace had been agreed. Promoting patronage at a local level was by then perceived as a necessary approach in the developing world to prevent the Soviets from developing relationships with the Europe's former colonies. The winding down of Britain's empire coincided with more serious Cold War threats and the need for effective 'western' approaches to both counter-insurgency and counter-terrorism to have global outreach.

As Brown clearly outlines in European Union, counter terrorism and police cooperation counter-terrorism involves a range of 'actions' which rest upon a changing legal basis as during the earlier colonial period. Informal police co-operation stemmed from the 1970s with the Trevi Group established to tackle international terrorism and then to address other areas of transnational crime within Europe. Following a series of legislative changes, it was not until 1998 that the Europol Convention provided the legal basis for Europol. It has never been a traditional EU agency but described as an 'international organisation' with its own legal framework funded by member states. The Convention has been amended three times and this has gradually extended Europol's mandate to dealing with issues of common interest including counter-terrorism, asylum, immigration, external border co-operation, combating drug addiction and fraud. As Brown has demonstrated, the path to European police co-operation has been all but smooth and Europol has often been held 'at arm's length' in terms of the operational side to policing with a primarily 'operative' role. Even with gradual amendments to Europol's legal framework and the easing of police co-operation, it was not until a second protocol was signed in 2002 that the basis for joint investigation teams was established, and then only in 2008 that most association agreements had been concluded. Brown's fine analysis demonstrates that despite a widely held view that police must cooperate beyond national boundaries to manage rising transnational crime and terrorism, Europe's progress in this sphere has been painfully slow

This raises the question as to the relevance of the 'British Way' within wider European (and international) counter-terrorism contexts. When considering the 
development of a legislative framework for police co-operation and counterterrorism, Brown notes that following 11 September 2001 the UK had the "most extensive array of counter-terrorist legislation" in all of the (then) fifteen EU member states. The Northern Ireland conflict which had spread to the UK mainland led to the Prevention of Terrorism Act provisions becoming statutory in 2000. In terms of counter-terrorism strategies it should be noted that the military's institutional memory had been built on earlier colonial COIN and then carried forward to create a Northern Irish legacy. Where it is not entirely clear is the extent to which the European Union 'added value' or eroded these principles when rising to challenge of European-wide counter-terrorist policies. It would appear that 'slippage' has occurred between EU-state-led proposals and the empirical realities - or the difference between what the decision-makers had argued for and their actual implementation. Clearly the widening and deepening of the European Union has the ability to weaken rather than strengthen multi-agency partnerships whether in counter-terrorism or aspects of transnational crime. This can be demonstrated by Europol's fragmented approaches to the management of both European and international policing missions including those to the Balkans and further afield in Georgia and Afghanistan. Within this context any attempt at bringing Britishness (not only through Europol but also the Serious Organized Crime Agency) is swallowed up by the wider European rhetoric. The "overall ongoing confusion over the purpose of a greater EU level of police activity" has led to difficulties in reaching agreements in relation to both human and drugs trafficking and terrorism, which may suggest that really effective counterterrorist strategies are better when home grown.

Here we turn to Lambert's Countering Al-Qaeda in London with a structure that uses four London underground stations (King's Cross, Finsbury Park, Brixton and Victoria) to consider "the geography and chronology of counter-terrorism police work". Lambert's charting of his counter-terrorism policing between 2002 and 2007 is the most controversial of the three books and came under extensive criticism from "some of the most influential voices in the British media and their transatlantic allies". Essentially this criticism reposed upon whether Lambert - and the work of his Metropolitan Police Special Branch (MPSB) colleagues in the Muslim Contact Unit (MCU) - was legitimate as well as effective in combating extremism within Muslim communities in London. This emanated, as Lambert noted, from the view that "a tension was perceived to exist between 'hard' investigative counter-terrorism and 'soft' community policing in support of counter-terrorism". Initially Lambert's approach was simply to encourage dialogue in relation to potential al-Qaeda threats to Britain with Muslim organisations and the representatives of Mosques in London. This developed further with MCU engaging with the Muslim Association of Britain and the Muslim Welfare House to challenge al-Qaeda influences within Brixton which included the Mosque. At no time, however, as Lambert makes clear, was there an intention to recruit Muslim community leaders as "covert human intelligence sources" (informants) aligning with 'harder' counter-terrorist policing, but to work with these 'London partnerships' to create a form of 'soft' community engagement. Certainly within the post-7/7 counter-terrorism policing context in England and Wales, there have been links forged between community-based and intelligencecentred policing models : more recent neighbourhood policing schemes are reliant in part on intelligence gathering. In these contexts it has been argued that police officers can persuade members of the community of the benefits in working closely with the police in relation to anti-social behaviour and crime, though the evidence that 
this works in relation to counter-terrorism is more limited and remains problematic. Despite the evidence to the contrary, Lambert reflects that "this case study approach provides compelling evidence that endorses legitimacy and effectiveness of the MCU partnership initiatives in Finsbury Park and Brixton"; the evidence coming, for example, from the removal of the extremist Abu Hamza and his supporters from Finsbury Mosque.

This issue here is that the MCU began their London partnerships' programme before the UK government's 'Preventing Violent Extremism' had been fully implemented. This counter-terrorism strategy was developed following $7 / 7$ and for example made financial contributions to almost 100 local authorities to help combat terrorism in their local areas whilst being specifically targeted to the alQaeda threat. Moreover, MPSB had been absorbed into a great counter-terrorism branch of MPS which was by then confronted by the Home Office and Security Services' "greater control of intelligence gathering and strategy". The backbone to this was the 2006 counter-terrorism strategy CONTEST: "to reduce the risk to the UK and its interests overseas from terrorism, so that people can go about their lives freely and with confidence". CONTEST has four strands: PROTECT (the defence of important buildings and the UK's infrastructure); PREVENT (preparation for the aftermath of a terrorist attack); PERSUE (arrest the perpetrators) and PREPARE (stop people from becoming or supporting terrorists). It is the latter - PREVENT that has formed the basis of a 'new' form of counter-terrorism to enable the police to prevent an act of terrorism before it has been committed and has been described as an 'anti-extremism' programme which requires police to work in partnership with other agencies and stakeholders within local society. It was within the PREVENT strand that the MCU London partnerships were considered to be working "to a discarded MPSB model that was out of kilter with the Association of Chief Police Officers thinking and the wider War on Terror" and raising questions in relation to the legitimacy of working with potential extremists. Lambert had advocated a 'softer' community and indeed truly 'hearts and minds' approach within his London experiment. He concludes that just prior to the submission of his research project, the United States General David Petraeus, in a lecture on military strategy in Afghanistan and the importance of tackling the terrorist threat in London, made reference to a decline in need for a 'hearts and minds' policing approach in favour of hard edge counter-insurgency and counter-subversive strategies. This, argued Lambert, paved the way for future counter-terrorism policing that would mirror the earlier Royal Ulster Constabulary and colonial Special Branch policing models and paradoxically endorse an older 'British way'.

Georgina Sinclair International Centre for Crime, Policing and Justice, The Open University - Walton Hall Milton Keynes MK7 6AA, UK g.s.sinclair@open.ac.uk 